\title{
Pengaruh Family Triple Support terhadap Nyeri pada Bayi saat Imunisasi Measles Rubella di Wilayah Kerja Puskesmas Pauh Kota Padang Tahun 2019
}

\author{
Dewi Susanti, Eravianti, Rati Purnama Sari, Dian Novita
}

\begin{abstract}
Abstrak
Nyeri akibat injeksi merupakan sumber distress bagi anak dan orang tua serta petugas saat imunisasi. Hal ini juga ditakutkan akan menimbulkan dampak jangka panjang pada anak berupa trauma akan pengalaman nyeri. Tujuan: Mengetahui pengaruh Family Triple Support (FTS) terhadap respon nyeri pada bayi saat imunisasi Measles Rubella (MR) di wilayah kerja Puskesmas Pauh Kota Padang tahun 2019. Metode: Penelitian ini menggunakan metode quasiexperiment dengan menggunakan post-test only group design yang dilaksanakan pada bulan September 2018 sampai bulan Juni 2019. Populasi dalam penelitian ini adalah bayi usia 9-11 bulan yang menjalani imunisasi MR di wilayah kerja Puskesmas Pauh. Teknik pengambilan sampel dengan purposive sampling mendapatkan 20 orang. Pada penelitian ini diberikan perlakuan FTS yaitu teknik menyusui dengan posisi sitting up dan pengalihan nyeri menggunakan krincingan pada bayi saat diimunisasi MR, kemudian melakukan observasi \pm 3 menit dengan tetap mempertahankan FTS menggunakan skala FLACC. Hasil: Nilai rerata respon nyeri pada bayi yang telah diberikan intervensi FTS sebesar 6,20, lebih rendah daripada kelompok yang tanpa diberikan intervensi dengan nilai rerata respon nyeri sebesar 7,40 . Selanjutnya dilakukan uji independent $t$-test didapatkan nilai $p=0,009<0,05$, berati Ho ditolak. Simpulan: Terdapatnya pengaruh FTS terhadap respon nyeri pada bayi saat imunisasi MR di wilayah kerja Puskesmas Pauh Kota Padang tahun 2019.
\end{abstract}

Kata kunci: family triple support, imunisasi measles rubella, nyeri

\begin{abstract}
Pain because of injection is a source of distress for children and parents and officers in immunization. It is also skeptically will cause the long term effects of trauma in children the experience of pain. Objectives: To determined the effect of Family Triple Support (FTS) on pain responses from infants during Measles Rubella (MR) immunization in the working area at Pauh in Health Center, Padang City in 2019. Methods: This study used a quasi-experimental method using post-test only groups design which was carried out in September 2018 until June 2019. The population of this study was infants aged between nine months until eleven months that underwent Measles Rubella immunization in the work area at Pauh in Health Center. The sampling technique with a purposive sampling of twenty of people. In this study, FTS treatment was given, namely breastfeeding technique with a sitting up position and the transfer of pain using curling in infants when MR immunized, then observing \pm 3 minutes while maintaining FTS using the FLACC scale. Results: Average value of pain response from infants that had been given an FTS intervention in 6.20, lower than the group of the intervention in an average value of pain response to 7.40. Independent T-test was $p=0.009$ $<0.05$. Conclusion: The influence of FTS on pain responses from infants during MR immunization in the working area at Pauh in Health Center, in Padang City in 2019.
\end{abstract}

Keywords: immunization measles rubella, triple family support, pain

Affiliasi penulis: Bagian Jurusan Kebidanan Poltekkes Kemenkes, Padang
Korespondensi : Dewi Susanti, Email:

dewipoltekkespadang@gmail.com 


\section{PENDAHULUAN}

Imunisasi merupakan tindakan efektif dalam pencegahan dan penurunan angka kesakitan akibat Penyakit yang Dapat Dicegah Dengan Imunisasi (PD3I) yang diperkirakan menyumbang 2 hingga 3 juta kematian tiap tahunnya. ${ }^{1}$ Salah satu Penyakit yang Dapat Dicegah Dengan Imunisasi (PD3I) adalah campak dan rubella. Tindakan kuratif yang diberikan pun kepada penderita campak dan rubella hanya bersifat supportif untuk meringankan gejala yang terjadi. $^{2}$

\section{Global Vaccine Action Plan (GVAP)} menargetkan 5 regional WHO dapat bebas campak dan rubella pada Tahun 2020. Sejalan dengan GVAP, The Global Measles \& Rubella Strategic Plan 20122020 memetakan strategi dalam upaya mencapai target dunia tanpa campak, rubella atau Congenital Rubella Syndrome (CRS). ${ }^{3}$ Salah satu strategi adalah pencapaian pemberian dua dosis vaksin yang mengandung campak dan rubella melalui imunisasi rutin dan tambahan dengan cakupan yang tinggi $>95 \%$ dan merata. ${ }^{4}$ Sesuai dengan komitmen Indonesia pada lingkup ASEAN dan SEARO dalam rangka mencapai target eliminasi campak dan rubella tahun 2020, dimana cakupan imunisasi campak dan rubella minimal $95 \%$ merata di seluruh kabupaten/kota. ${ }^{2}$

Kementerian Kesehatan Republik Indonesia mencatat jumlah kasus campak dan rubella yang ada di Indonesia sangat banyak dalam kurun waktu lima tahun terakhir. Tahun 2016 tercatat 12.730 kasus suspek campak-rubella (2.949 positif campak dan 1.341 positif rubella) mengalami peningkatan pada tahun 2017 tercatat 15.104 kasus suspek campakrubella (2.197 positf campak dan 1.284 positif rubella) dan sampai dengan Juli 2018 tercatat 2.389 kasus suspek campak-rubella (383 positif campak dan 732 positif rubella). ${ }^{3}$

Pemerintah menggencarkan kampanye cakupan imunisasi MR sebagai indikator keberhasilan. Tahun 2017 Indonesia memiliki cakupan imunisasi MR yaitu sebesar $89,8 \%$. Dimana hanya 8 provinsi yang mencapai target cakupan imunisasi MR >95\% dan 26 provinsi yang tidak mencapai target cakupan imunisasi MR, termasuk diantaranya Provinsi Sumatera Barat. ${ }^{5}$

Provinsi Sumatera Barat yang terdiri dari 19 Kabupaten/Kota pada tahun pada tahun 2017 cakupan imunisasi MR sebesar $82,2 \%$, dimana terdapat 3
Kabupaten/Kota yang telah berhasil mencapai target cakupan imunisasi MR $>95 \%$ dan sisanya belum mencapai target cakupan imunisasi MR $>95 \%$ diantaranya Kota Padang. ${ }^{6}$ Kota Padang terdiri 22 puskesmas memiliki cakupan imunisasi MR sebesar $88 \%$, dimana terdapat 3 puskesmas telah berhasil mencapai target dan sisanya belum mencapai target diantaranya Puskesmas Pauh yang memiliki cakupan imunisasi MR sebesar 91,35 \%. ${ }^{7}$

Upaya dalam menekan angka kejadian kasus campak dan rubella memiliki beberapa tantangan, salah satunya rasa nyeri saat imunisasi $\mathrm{MR}^{8}$ Imunisasi MR pertama kali diberikan pada usia bayi 9 bulan dimana pada usia tersebut bayi lebih mudah mengeksperikan kesakitan yang diterimanya dari pada bayi muda usia 0-2 bulan yang memiliki ketidakmampuan membedakan rangsangan dari rasa sakit. ${ }^{9}$ Hasil penelitian lain juga menunjukkan bahwa respon nyeri pada bayi yang memperoleh imunisasi dasar campak lebih tinggi rerata skornya 6,1 dibandingkan dengan respon nyeri pada bayi imunisasi DPT combo dimana rerata skornya 5,7. ${ }^{10}$

Nyeri yang berhubungan dengan injeksi merupakan sumber distress tidak hanya untuk anak, tetapi juga bagi orang tua dan petugas yang melakukan injeksi. Hal berisiko menimbulkan dampak jangka panjang berupa trauma akan pengalaman nyeri saat imunisasi. ${ }^{11}$ Apabila hal tersebut tidak ditangani dengan baik, dapat menyebabkan dampak psikologis pada anak dan tentunya akan mengganggu perkembangan anak. Sehingga untuk mengurangi dampak psikologis dari tindakan yang diberikan, atarumatic care sebagai bentuk perawatan terapeutik, dapat diberikan kepada anak dan keluarga. ${ }^{12}$

Atraumatic care mempunyai banyak metode yang dapat diterapkan namun salah satu metode yang paling murah dan aman untuk dilakukan adalah metode Family Triple Support (FTS). FTS adalah intervensi terintegrasi yang melibatkan peran orang tua dalam mengatasi permasalahan nyeri saat prosedur imunisasi bayi. Intervensi ini terdiri atas pemberian informasi tentang metode reduksi nyeri pada bayi dan dilanjutkan dengan pelaksanaan metode mengurangi nyeri saat prosedur imunisasi pada bayi. Metode mengurangi nyeri yang ditawarkan dalam FTS berupa pemberian Air Susu lbu (ASI) dengan posisi bayi sitting up (posisi kepala lebih tinggi 
dari ekstremitas bawah) diikuti dengan distraksi menggunakan mainan bersuara (krincingan). ${ }^{12}$

Strategi FTS dapat menurunkan nyeri dengan cara memberi banyak stimulus sehingga menghambat impuls nyeri ke otak, didasari bahwa aktivitas retikuler dapat menghambat nyeri jika seseorang diberi stimulus yang banyak maka akan menghambat input sensori nyeri sampai ke otak. Pemberian ASI oleh ibu kandung bayi dan stimulus yang menyenangkan seperti dengan yang menimbulkan bunyi, dengan berbagai macam warna mainan dapat merangsang sekresi endorphin sehingga memblok transmisi nyeri. Endorphin merupakan asam amino yang mengikat reseptor opiate yang berada di otak yang dapat memberi efek analgesik. ${ }^{13}$

Sebuah penelitian menyebutkan selisih rerata respon nyeri responden yang diberikan FTS berbasis atraumatic care lebih rendah dibandingkan dengan selisih rata-rata respon nyeri yang tidak diberikan FTS berbasis atraumatic care. ${ }^{13}$ Penelitian yang lain yang bertujuan untuk mengetahui efektifitas pemberian ASI pada penuruan nyeri selama injeksi imunisasi pada bayi menunjukkan pemberian ASI dan skin-to-skin contact secara signifikan mampu menurunkan intensitasi menangis pada bayi yang dapat injeksi imunisasi. ${ }^{14}$ Interaksi antara ibu dan bayi saat menyusui menimbulkan rasa nyaman, aman dan hangat bagi bayi. Perasaan ini mengingatkan bayi akan nyamannya berada dalam rahim ibu, sehingga bayi menikmati kegiatan menyusui. ${ }^{15}$

Berdasarkan survey awal dengan mengamati lima orang bayi yang diimunisasi MR belum ada tindakan yang menjadi kebijakan khusus terkait dengan pentalaksanaan nyeri pada bayi yang di imunisasi. Tindakan yang biasa dilakukan adalah dengan menggendong bayi yang telah diberikan imunisasi. Alasan tindakan tersebut karena mudah dilakukan oleh pengantar bayi (orang tua, pengasuh atau kerabat) dan dipercaya dapat mengurangi tangisan bayi. Adapun tindakan pemberian seperti sukrosa atau dektosa tidak dilakukan karena cairan tersebut tidak tersedia di puskesmas. Tindakan menyusui tidak juga dilakukan karena pengantar bayi tidak selalu ibu bayi melainkan diwakili oleh wali bayi.
Berdasarkan fenomena di atas, perlu dilakukan penelitian tentang pengaruh Family Triple Support terhadap respon nyeri pada bayi saat imunisasi Measles Rubella (MR) di wilayah kerja Puskesmas Pauh Padang Kota Padang tahun 2019.

\section{METODE}

Metode yang digunakan pada penelitian ini adalah quasi-experiment with post-test only group design. Penelitian ini dilaksanakan di wilayah kerja Puskesmas Pauh Kota Padang pada bulan September 2018 hingga Juni 2019. Populasi dalam penelitian ini adalah bayi usia 9-11 bulan yang menjalani imunisasi MR di wilayah kerja Puskesmas Pauh. Pengambilan sampel menggunakan teknik purposive sampling sebanyak 20 bayi yang terdiri dari 10 sampel kelompok eksperimen (5 laki-laki dan 5 perempuan) dan 10 sampel untuk kelompok kontrol (5 laki-laki dan 5 perempuan). Pemilihan sampel menggunakan kriteria inklusi dan eksklusi. Kriteria inklusi terdiri dari: kesedian menjadi responden; ibu masih memberikan ASI kepada bayi; dan bayi datang bersama ibu. Kriteria eksklusi terdiri dari: bayi menderita sakit seperti demam, ikterus atau masalah kesehatan lainnya dan bayi yang mengalami kelainan kongenital seperti labioskizis atau labiopalatoskizis.

Data primer diperoleh dengan observasi mengunakan skala nyeri FLACC pada bayi yang memperoleh imunisasi MR. Sedangkan data sekunder yang digunakan berupa data tentang kunjungan bayi yang memperoleh imunisasi MR, dari laporan bulanan Puskesmas Pauh Kota Padang. Analisis data menggunakan independent-t test.

\section{HASIL}

Pengambilan data semua responden dalam penelitian ini telah memenuhi kriteria yang telah ditentukan. Dilakukan penilaian karakteristik responden berdasarkan jenis kelamin, Distribusi dari karakteristik responden dapat dilihat pada tabel di berikut: 
Tabel 1. Intensitas nyeri responden di wilayah kerja Puskesmas Pauh kota Padang tahun 2019

\begin{tabular}{lcc}
\hline Intensitas Nyeri & FTS & tidak FTS \\
\hline Rerata \pm SD & $6,20 \pm 1,13$ & $7,40 \pm 1,65$ \\
Median & 6 & 8 \\
Minimun & 4 & 4 \\
Maksimum & 8 & 9 \\
$\mathrm{~N}$ & 10 & 10 \\
$\mathrm{p}^{*}$ & 0,479 & 0,115 \\
\hline${ }^{*}$ shapiro wilk test & &
\end{tabular}

${ }^{*}$ shapiro wilk test

Berdasarkan Tabel 1 diperoleh rerata intensitas nyeri pada kelompok responden yang diberi FTS sebesar 6,20 $\pm 1,13$ dan pada kelompok kontrol

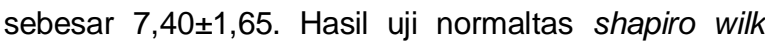
test menunjukkan bahwa data pada kelua kelompok berdistribusi normal. Sehingga memenuhi syarat untuk dilakukan uji parametrik.

Tabel 2. Pengaruh FTS terhadap Intensitas Nyeri pada bayi saat Imunisasi MR di wilayah kerja Puskesmas Pauh Kota Padang tahun 2019

\begin{tabular}{lccc}
\hline $\begin{array}{c}\text { Intensitas } \\
\text { Nyeri }\end{array}$ & FTS & tidak FTS & p \\
\hline Rerata $\pm S D$ & $6,20 \pm 1,13$ & $7,40 \pm 1,65$ & 0,009 \\
Median & 6 & 8 & \\
Minimun & 4 & 4 & \\
Maksimum & 8 & 9 & \\
$\mathrm{~N}$ & 10 & 10 & \\
\hline${ }^{*}$ independent $t$-test & & &
\end{tabular}

Berdasarkan Tabel 2 terlihat bahwa rerata intensitas nyeri pada kelompok yang diberi tindakan FTS $(6,20 \pm 1,13)$ lebih rendah dibandingkan kelompok yang tidak memperoleh FTS $(7,40 \pm 1,65)$. Hasil uji independent $t$-test menunjukkan adanya perbedaan yang signifikan antara kedua kelompok, dengan $\mathrm{p}=$ $0,009<0,05$.

\section{PEMBAHASAN}

Tingkat atau respon nyeri pada bayi dalam penelitian ini diukur dengan menggunakan skala nyeri perilaku FLAAC (Face, Legs, Activity, Cry, Consolability). Adapun penilaian tersebut adalah eksperesi wajah (Face) skor 0-2, gerakan kaki (Legs) skor 0-2, aktivitas (Activity) skor 0-2, menangis (Cry) skor 0-2, dan kemampuan dihibur (Consolability) skor $0-2$. Adapun hasil skor perilakunya adalah 0 : untuk rileks dan nyaman, 1-3: nyeri ringan, 4-6: nyeri sedang, dan 7-10: nyeri berat.

Penelitian ini dibagi atas 2 kelompok, dimana bayi yang telah diberikan imunisasi dengan penyuntikan diberikan intervensi FTS yaitu sebanyak 10 bayi dan tidak diberikan perlakuan sebanyak 10 bayi pula, kemudian dilakukan pengamatan sampai dengan \pm 3 menit dengan menggunakan lembar skala nyeri perilaku FLAAC. Hasil penelitian ini menunjukkan nilai rata-rata respon nyeri pada bayi yang telah diberikan perlakuan FTS lebih rendah dibandingkan kelompok yang tidak diberi perlakuan FTS. Pada penelitian ini, kelompok Family Triple Support (FTS) merupakan kelompok yang melibatkan langsung peran dari orangtua bayi yaitu ibu. Dimana selain ibu akan memberikan ASI dengan posisi sitting up saat penyuntikan imunisasi, juga memberikan distraksi berupan mainan bersuara (krincingan).

Hasil penelitian ini sejalan dengan hasil penelitian lain tentang pengaruh FTS berbasis atraumatic care menunjukkan selisih rata-rata respon nyeri yang bermakna pada kelompok intervensi FTS yaitu 4,02 sedangkan kelompok kontrol yaitu 5,74. Dimana rata-rata respon nyeri bayi yang diberikan intervensi FTS lebih rendah dibandingkan dengan pada kelompok kontrol. ${ }^{13}$

Penelitian serupa mengenai efek pemberian ASI terhadap tingkat nyeri dan lama tangisan bayi saat penyuntikan imunisasi, menjelaskan bahwa dengan derajat kepercayaan 95\% dan kekuatan uji $80 \%$ diperoleh hasil, bayi yang diberikan ASI tingkat nyerinya lebih rendah dibandingkan dengan bayi pada kelompok yang tidak diberikan ASI. ${ }^{14}$

Hal ini sejalan pula dengan penelitian lain yang mengatakan bahwa selama menyusui, bayi yang ada dalam dekapan ibunya akan merasa tenang, nyaman dan aman, tidak hanya karena kehangatan, melainkan juga karena bau yang familier (feronom). ${ }^{16}$ Dekapan memberikan rasa tenang, senang, aman dan nyaman dengan merangsang saraf sensoris dan motoris pada bayi, karena dalam kulit terdapat banyak ujung saraf yang bisa mencerminkan emosi seseorang sehingga jika disentuh mudah sampai ke otak. ${ }^{17}$

FTS dalam penelitian ini melibatkan pemberian ASI oleh ibu bayi. Kegiatan menyusui dengan posisi sitting up dapat memberikan kenyamanan kontak (contact comfort) kepada bayi karena selama 
menyusui ada kontak/ sentuhan antara ibu dengan bayinya yang dapat menimbulkan rasa nyaman dan hangat bagi bayi. Perasaan nyaman dan hangat ini mengingatkan bayi akan nyamannya berada di dalam rahim ibu, sehingga bayi menikmati kegiatan menyusui. Pada saat menyusui bayi akan merasakan kehangatan, kelembutan dan kasih sayang dalam dekapnya, dan dapat merangsang panca indera penglihatan, pendengaran, penciuman, rasa, bahkan sensasi raba. ${ }^{18}$

Penelitian yang menggunakan teknik sitting up dengan tujuan untuk mengetahui perbedaan posisi bayi antara posisi sitting up dengan supine terhadap respon nyei saat imunisasi bayi. Penelitian menggunakan quasy experiment dengan dua grup intervensi dengan desin pre-post test. Hasil penelitian menunjukkan posisi sitting up lebih membuat bayi nyaman dari pada posisi supine sehingga dapat mengurangi terjadinya nyeri saat injeksi. ${ }^{13}$

Hasil penelitian yang dilakukan tentang efektifitas teknik distraksi audiovisual pada anak selama dan setelah imunisasi, menunjukkan skor nyeri yang rendah pada kelompok distraksi dibandingkan kelompok kontrol pada anak yang diimunisasi. ${ }^{14}$

Penelitian pendukung lainnya menyatakan bahwa bayi yang diberikan intervensi PDK berisi parent led intervention yaitu teknik distraksi yang dilakukan orang tua melalui alat permainan dan katakata yang menenangkan, memiliki skor respon perilaku nyeri bayi lebih rendah dibandingkan dengan kelompok kontrol dan berbeda secara signifikan. ${ }^{12}$

Nyeri yang timbul pada saat imunisasi atau bahkan saat setelah imunisasi terjadi karena beberapa faktor yang mempengaruhi. Nyeri bersifat individual yang dipengaruhi oleh genetik, latar belakang kultural, umur dan jenis kelamin. ${ }^{19}$ Faktor-faktor yang dapat mempengaruhi nyeri antara lain: (1) Faktor fisiologi, seperti usia, jenis kelamin, kelelahan dan fungsi neurologi; (2) Faktor sosial: perhatian klien, pengalaman sebelumnya, dukungan keluarga dan social; (3) Faktor spiritual; (4) Faktor psikologi: tingkat kecemasan, pola koping; (5) Faktor budaya: makna nyeri, budaya. ${ }^{20}$

Berdasarkan hasil yang didapatkan pada kelompok kontrol terdapat skor terendah 4 sama dengan skor terendah pada kelompok eksperimen. Hal tersebut dimungkinkan karena pada saat pemberian perlakuan FTS dan tanpa perlakuan, bayi didekap atau digendong oleh sang ibu sehingga mempengaruhi psikologis bayi. Rasa aman dan nyaman yang dirasakan membuat bayi tidak memberikan respon nyeri yang berlebihan. Namun pada saat imunisasi diberikan, ada yang memberi dekapan ada juga yang tidak sehingga skor tertinggi didapatkan pada kelompok kontrol 9 tidak sama pada kelompok eksperimen yang selalu memberi dekapam dimana skor tertingginya 8. Dimana skor tertinggi tersebut di peroleh pada bayi perempuan dimana pada keompok perlakuan FTS sebesar 3 dan yang tidak diberi perlakuan FTS sebesar 4. Hal ini mungkin dikarenakan faktor fisiologis yaitu perbedaan jenis kelamin dan faktor psikologis bayi dikarenakan dekapan tersebut.

\section{Pengaruh Family Triple Support terhadap Respon Nyeri pada Bayi Saat Imunisasi Meales Rubella}

Berdasarkan hasil penelitian didapatkan adanya pengaruh FTS terhadap respon nyeri pada bayi saat imunisasi MR di wilayah kerja Puskesmas Pauh Kota Padang tahun 2019. Hal ini memiliki kesamaan dengan hasil penelitian yang dilakukan lainnya tentang pengaruh FTS berbasis atraumatic care menunjukkan rata-rata respon nyeri bayi yang diberikan intervensi FTS lebih rendah dibandingkan dengan pada kelompok kontrol. ${ }^{13}$

Berdasarkan penelitian lainnya tentang pengaruh FTS berbasis atraumatic care terhadap respon bayi saat imunisasi DPT hasil penelitian didapatkan perbedaan signifikan dimana ada pengaruh FTs terhadap respon bayi saat imunisasi DPT. ${ }^{21}$ Menurut sebuah penelitian didapatkan hasil dimana menunjukkan bahwa tingkat nyeri bayi yang diukur dengan skala FLACC dan skala RIPS yang berbeda signifikan, saat penyuntikkan pada bayi yang diberi ASI lebih rendah dibandingkan pada bayi yang tidak diberi ASI. ${ }^{22}$

Strategi FTS dapat menurunkan nyeri dengan cara memberi banyak stimulus sehingga menghambat impuls nyeri ke otak, ini didasari bahwa aktivasi retikuler dapat menghambat nyeri dimana jika seseorang diberi stimulus yang banyak maka akan menghambat input sensori nyeri sampai ke otak. ${ }^{14}$ Pemberian ASI oleh ibu kandung bayi dan stimulus yang menyenangkan seperti dengan yang 
menimbulkan bunyi, dengan berbagai macam warna mainan dapat merangsang sekresi endorphin. ${ }^{14}$ Sesuai dengan teori gate kontrol, adanya stimulasi nyeri membuat gerbang terbuka yaitu pada saat dilakukan penyuntikan imunisasi. ${ }^{18}$

Pemberian intervensi FTS mengakibatkan pada respon nyeri terjadi perubahan yang nampak pada: ${ }^{18}$

1. Faktor fisik: pemberian analgesik berupa FTS yaitu tindakan menyusui dengan posisi sitting dan distraksi mainan;

2. Faktor emosional: suasana hati bayi yang baik karena pemberian ASI oleh ibunya membuat bayi merasa nyaman dan aman, serta permainan distraksi yang membuat bayi senang;

3. Faktor perilaku: perhatian bayi lebih mudah dialihkan dengan memberikan distraksi mainan bersuara (krincingan).

Respon nyeri bayi saat imunisasi biasanya disebabkan karena pengaruh psikologis berupa kurangnya rasa nyaman yang dirasakan bayi oleh karena kurangnya dukungan orang tua dan pengaruh fisik akibat dari ketidaknyamanan berupa injeksi vaksin. Oleh karena itu, strategi FTS dapat menurunkan nyeri dengan cara memberi banyak stimulus yaitu pemberian ASI, posisi sitting up dan pengalihan nyeri dengan krincingan sehingga bayi merasa nyaman karena didekap dan diperhatikan, sehingga dapat menghambat impuls nyeri ke otak. Sesuai dengan hasil penelitian yang dilakukan peneliti dimana ada pengaru FTS terhadap respon nyeri pada bayi saat imunisasi measles rubella.

\section{SIMPULAN}

Terdapat pengaruh FTS terhadap respon nyeri pada bayi saat imunisasi MR di Puskesmas Pauh Kota Padang tahun 2019.

\section{UCAPAN TERIMA KASIH}

Terima kasih kepada semua pihak yang telah memberikan kontribusi dalam penelitian ini.

\section{DAFTAR PUSTAKA}

1. Pusat Data dan Informasi Kementerian Kesehatan RI. Situasi imunisasi di Indonesia. Jakarta: Kementerian Kesehatan RI (Kemenkes RI); 2016.

2. Pusat Data dan Informasi Kementerian Kesehatan RI. Situasi dan analisis imunisasi. Jakarta: Kemenkes RI; 2016.

3. Dirjen PP dan PL. Petunjuk teknis kampanye imunisasi measles rubella (MR). Jakarta: Kemenkes RI; 2017.

4. Kemenkes RI. Profil kesehatan RI 2017. Data dan Informasi. Jakarta: Kemenkes RI; 2018.

5. Kemenkes RI. Panduan pelaksana pekan imunisasi dunia. Jakarta: Kemenkes RI; 2017.

6. Dinas Kesehatan (Dinkes) Sumbar. Profil tahun 2017. Padang: Dinkes Sumbar; 2018.

7. Dinkes Kota Padang. Profil kesehatan kota Padang tahun 2017. Padang: Dinkes Kota Padang; 2018.

8. Harianti M, Mediani HS, Nurhidayah I. Pengaruh breastfeeding terhadap intensitas nyeri pada bayi yang mendapat imunisasi: literature review. JAMC idea's. 2017;4(2).

9. Soetjiningsih. Tumbuh kembang anak. Jakarta: EGC; 2016.

10. Sarimin S, Moningka L, Jansen A. Gambaran respon perilaku nyeri bayi pada pemberian suntikan imunisasi dasar di Puskesmas Bahu Kecamatan Malayang Kota Manado. Jurnal IImiah Perawat Manado. 2015;4(1):92676.

11. Aziz A, Hidayat A. Praktik klinik: aplikasi dasardasar praktik kebidanan. Jakarta: Salemba Medika; 2011.

12. Sarimin SD. Efektivitas paket dukungan keluarga (PDK) terhadap respon perilaku nyeri bayi yang dilakukan prosedur imunisasi di RSUD Prof. Dr. R.D. Kandou Manado [tesis]. Jakarta: Fakultas Keperawatan Universitas Indonesia; 2012.

13. Putra IB. Guptayana PS, Windastra IM, Gandasari NA. Pengaruh family triple support (FTS) berbasis atraumatic care terhadap respon nyeri bayi saat imunisasi di Puskesmas I Denpasar Barat [tesis]. Denpasar: Keperawatan, Universitas Udayana; 2014. 
14. Ahriani S. Perbedaan efektivitas pemberian family triple support (FTS) dengan kompres hangat terhadap respon nyeri bayi pasca imunisasi [skripsi] Makassar: Kedokteran dan IImu Kesehatan, UIN Alauddin; 2017.

15. Astuti IT. Studi komparasi pemberian asi dan larutan gula terhadap respon nyeri saat imunisasi pada bayi di Puskesmas Ngesrep Semarang [tesis]. Jakarta: Fakultas IImu Kesehatan, Universitas Indonesia; 2011.

16. Ibrahim ARA. Menyusui: proses melekatkan ikatan batin ibu dan bayi, Indonesia menyusui. Jakarta: Badan Penerbit IDAI; 2010.

17. Aryani YP. Pengaruh family triple support (FTS) berbasis atraumatic care terhadap respon nyeri pada bayi saat imunisasi DPT 1 BPM Wiji Prihanti Sruweng Kebumen [diploma]. Gombong: Sekolah Tinggi Ilmu Kesehatan Muhammadiyah; 2017.
18. Pusat Pendidikan dan Pelatihan Tenaga Kesehatan. Modul keperawatan anak 1 (kegiatan belajar II) Atraumatic. Jakarta. 2015.

19. Judha M, Sudarti, Fauziah A. Teori pengukuran nyeri \& nyeri persalinan. Yogyakarta: Yuha Medika; 2012.

20. Barber P, Robertson D. Intisari farmakologi untuk perawat. Jakarta: EGC; 2012.

21. Vioneery D, Andari FN. Pengaruh family triple support (FTS) berbasis atraumatic care terhadap respon nyeri pada bayi saat imunisasi DPT di Puskesmas Sukamerindu Kota Bengkulu. Jurnal Keperawatan Muhammadiyah, Bengkulu; 2012.

22. Rahayuningsih SI. Efek pemberian ASI terhadap tingkat nyeri bayi saat penyuntikaan imunisasi di Kota Depok. Idea Nursing Journal. 2012;103-116, 2087-2879. 